\title{
KILKA UWAG O TWÓRCZOŚCI STANISŁAWA BRZOZOWSKIEGO W PRZESTRZENI STUDIÓW POSTKOLONIALNYCH
}

\author{
KRZYSZTOF KRASUSKI 1 \\ (Katowice)
}

\begin{abstract}
Słowa kluczowe: twórczość Stanisława Brzozowskiego, polski modernizm, krytyka literacka, postkolonialna teoria i krytyka

Keywords: Stanisław Brzozowski work, Polish modernism, literary criticism, postcolonial theory and critique
\end{abstract}

\begin{abstract}
Abstrakt: Krzysztof Krasuski, KILKA UWAG O TWÓRCZOŚCI STANISŁAWA BRZOZOWSKIEGO W PRZESTRZENI STUDIÓW POSTKOLONIALNYCH. „PORÓWNANIA” 11, 2012, Vol. XI, ss. 43-52, ISSN 1733-165X. Tematem artykułu jest innowacyjna teza, że do szeregu dotychczasowych opracowań twórczości wybitnego krytyka Stanisława Brzozowskiego (18781911) należy także dołączyć teorię studiów postkolonialnych. Artykuł prezentuje argumenty wskazujące na to, iż kontekst studiów postkolonialnych jest właściwy dla interpretacji kulturoznawczych i krytycznoliterackich esejów oraz powieści Brzozowskiego, czołowego przedstawiciela polskiego modernizmu. Twórczość jego przypada na przełomowy okres wyzwalania się Polski spod zaborów w przededniu odzyskania niepodległości. Brzozowski w swoich utworach zarysował perspektywę konieczności modernizacji kultury polskiej i przejścia życia społecznego z zacofanej fazy XIX-wiecznego kolonializmu do współczesności. Dlatego kategorie i pojęcia teorii studiów postkolonialnych wydają się niezbędnym składnikiem analiz i interpretacji całości twórczości pisarza.
\end{abstract}

Abstract: Krzysztof Krasuski, SOME REMARKS ON THE WORK OF STANISŁAW BRZOZOWSKI WITHIN THE SPACE OF POSTCOLONIAL STUDIES. „PORÓWNANIA” 11, 2012, Vol. XI, pp. 43-52, ISSN 1733-165X. The subject of the article is an innovative thesis that the theory of postcolonial studies should be included into the range of comments on the works of the famous critic: Stanisław Brzozowski (1878-1911). The article presents the arguments which indicate that the context of postcolonial studies is appropriate for interpretation cultural and literal essays as well as novels of Brzozowski - the outstanding representative of Polish modernism.

\footnotetext{
${ }^{1}$ Correspondence Address: krzysztof.krasuski@us.edu.pl
} 
He used to write in the critical period in which Poland was freeing itself from annexation. Brzozowski insisted on necessity of modernization of Polish culture and Polish social life. That is why the notion of postcolonial studies seems to be crucial in analyses and interpretations of Brzozowski's work.

Od ponad stu lat nie ma końca różnorodnym interpretacjom dzieła Stanisława Brzozowskiego (1878-1911). Jest tak, ponieważ ten filozof, pisarz i krytyk literacki w swoich tekstach wybiegał daleko poza sprawy ściśle literackie. Na marginesach analiz literatury podejmował swe zasadnicze treści: zagadnienia doniosłe dla zrozumienia nie tylko kultury i sztuki, ale i stylu życia społecznego, w tym także podstaw bytu narodowego nie tylko w okresie okupacji kraju przez zaborców, ale także w czasie postkolonialnej przyszłości Polski, zarysowującej się na początku ubiegłego wieku, jeszcze przed śmiercią pisarza. Nietrudno skonstatować, że o ile związek twórczości Brzozowskiego z nurtami filozofii przełomu XIX i XX wieku dzisiaj pozostaje jedynie mniej lub bardziej istotny dla współcześnie utrzymującego się znaczenia jego pism, czego dowodzą kolejne dekady popularności tego pisarza wśród społecznej elity, o tyle ich aspekty kulturowe (np. treści z zakresu filozoficznej antropologii, konteksty postsekularne, postkolonialne i ogólnie rzecz biorąc - ponowoczesne) nadal przysparzają okazji do namysłu nad fenomenem tej twórczości², od lat świadczącej o jej nieustającej intelektualnej wartości. Fenomen ten polega m.in. na ciągłej możliwości odkrywania w pismach Brzozowskiego tych problemów nowoczesnych społeczeństw, na które do tej pory nie zwracano się uwagi bądź traktowano tylko marginalnie. Do tego obszaru myśli autora Głosów wśród nocy należą zagadnienia, które dają się określić w kategoriach teorii kolonialnej/postkolonialnej.

Na przykład, rekonstruowany przez Dorotę Kozicką program krytycznoliteracki Brzozowskiego nasuwa badaczce skojarzenia ze sformułowaną przez Rolanda Barthesa teorią praktyki wytwarzania znaczeń tekstu i jego otwarciem na wiele kodów kultury33. Jest to obserwacja mogąca inspirować dalsze wielokierunkowe interpretacje poglądów polskiego krytyka. Sądzę więc, że należy pokusić się o dokładniejsze określenie każdorazowego rodzaju performatywności tekstów Brzozowskiego, ich adresu i kontekstu społecznego, motywacji nadawczej itp. Jestem przekonany, że wśród czynników genezy i funkcji tych tekstów z powo-

\footnotetext{
2 Por. R. Nycz, Wywotywanie świata. Zadania krytyki i sztuki w pisarstwie filozoficznym Stanistawa Brzozowskiego, w: idem, Jezyk modernizmu. Prolegomena historycznoliterackie. Wrocław 1997, s. 147, 152.

${ }^{3}$ D. Kozicka, "Umyst w stanie nieustannego tworzenia”. O krytyce Stanistawa Brzozowskiego jako akcie performatywnym. „Teksty Drugie” 2011, nr 5.
} 
dzeniem mogłyby się znaleźć także pojęcia zaczerpnięte z leksykonu teorii studiów postkolonialnych. Metodologia ta umożliwia bowiem wprowadzenie m.in. w analizowaniu twórczości Brzozowskiego, dotychczas nie używanych narzędzi poznawczych, służących innowacyjnej interpretacji stanu postkolonialnej oczywistości, w której znalazły się polska literatura i kultura w XIX i XX wieku. Łatwo zauważyć, iż myśl Brzozowskiego dobrze odnajduje się w nowych czasach. Nie można jej uznać za przeterminowaną i nieistotną. Dlaczego? Bo znajduje ona oparcie we współczesnych teoriach interpretacji humanistycznej, np. postsekularnej, ale także i postkolonialnej.

Wokół wielu aspektów i wątków myśli przedwcześnie zmarłego pisarz powstała i stale powiększa się wielka biblioteka najrozmaitszych studiów i rozpraw. Ten ogromny stan badań nad pisarstwem Brzozowskiego przekonuje, że nie jest proste - jak zauważa Bohdan Cywiński - „określenie niejako wspólnego mianownika, który pozwoliłby zestawić jego tezy światopoglądowe, filozoficzne, ideologiczne, kulturowe czy literackie [...] choć czytając jego prace [...] odbiera się wrażenie, że formułowane $\mathrm{w}$ nich poglądy $\mathrm{z}$ różnych dziedzin [...] są zakorzenione w jednym i tym samym gruncie jakiejś wizji rzeczywistości" ${ }^{4}$. Nie przesądzając o ilości tych gruntów, w tej kwestii uważam, iż należy rozważyć, czy przypadkiem nie jest to - przynajmniej $w$ jakimś stopniu, który oczywiście także nie wyjaśni wszystkich problemów poznawczych, gromadzących się wokół wyjaśniania twórczości Stanisława Brzozowskiego - wizja skonstruowana na przecięciu się i na przełomie domeny kolonializmu oraz postkolonializmu. Sądzę, że ten obszar warto wziąć pod uwagę w tym wypadku. Dlatego też do długiego szeregu woluminów prac o Brzozowskim chciałbym dołączyć i ten skromny przypis. Sugeruję sensowność i potrzebę umieszczenia spuścizny pisarza w perspektywie studiów nad kolonializmem i postkolonializmem, który to horyzont, jak dotąd, nie znalazł się w polu badań nad pisarstwem Stanisława Brzozowskiego ${ }^{5}$.

W niniejszych uwagach łączę wytyczne nowych propozycji i zwrotu w badaniach literackich wprowadzonego przez teorię studiów postkolonialnych z konkretem historycznoliterackim, którym jest dorobek autora Legendy Młodej Polski. Chcę zachować się pragmatycznie i aplikować teorię do społecznej i literackiej empirii. Można rzec, iż twórczość Brzozowskiego odzwierciedla dwie fazy społecznej historii: sytuuje się na pograniczu pierwszej w warunkach polskich transformacji kolonializmu i postkolonializmu.

${ }^{4}$ B. Cywiński, Rodowody niepokornych, Warszawa 2010, s. 357. Por. idem, Narodowe i ludzkie w myśli Stanistawa Brzozowskiego, w: Wokót myśli Stanistawa Brzozowskiego. Red. A. Walicki, R. Zimand. Kraków 1974, s. 257-276.

5 Por. D. Skórczewski, Dlaczego Polska powinna się upomnieć o swoja postkolonialność, „Znak” 2007, nr 9; Studia postkolonialne nad kultura i cywilizacją polska. Red. K. Stępnik, D. Trześniowski. Lublin 2010. 
Zgłaszam tę innowacyjną propozycję lektury tekstów Brzozowskiego, która w pewnej mierze chce być odpowiedzią na dotychczasowe dylematy historyków literatury i kultury, przedstawiających kontrowersyjne klasyfikacje twórczości pisarza. Określano go w przeszłości, pomijam tu znane wulgaryzujące recenzje międzywojennych i powojennych marksistów, jako ideologa: poważny esej Bohdana Cywińskiego nosi tytuł Radykał na zakręcie historii. To bardzo konkretny wiraż na historycznym trakcie wyznaczanym polskimi datami 1863 - 1905 - 1918 a przebiegającym od okresu zaborczych kolonii do specyficznego dwudziestowiecznego kolonializmu.

Natomiast Tomasz Burek i Marta Wyka zajmowali się głównie poetyką w powiązaniu z światopoglądem powieści pisarza i filozofa, sytuując je w kręgu arcydzieł 6 . Decyzje te można w pewnym stopniu uznać za dyskusyjne. Wielu innych interpretatorów wskazywało na swoiste pęknięcia i rozdwojenia osobowości i twórczości pisarza. Możliwości ich integracji stwarza przyjęcie perspektywy wyjaśniającej stwarzanej przez studia postkolonialne. Jak się wydaje, Brzozowski we wszystkich uprawianych przez siebie formach literackich, esejach, powieściach, publicystyce, zamierzał pisarsko „zdekolonizować” a nie jedynie skrytykować czy zdyskredytować anachronizmy świadomości i kultury narodowej. Nasz pisarz, podobnie jak dziś czyni to np. Gayatri Ch. Spivak - i myślę, że nie jest nadużyciem ta odległa w czasie analogia - dążył do osiągnięcia postkolonialnego intelektualisty, reprezentującego krytykę interwencyjną i zaangażowaną i związaną z tym strategię ${ }^{7}$. Argumentami Brzozowskiego była analiza i literackie zobrazowanie kolonialnych wzorów zachowań i kultury (np. „fantazmaty” polskiego romantyzmu i postromantycznego romansu rodzinnego m.in. Rodzina Potanieckich H. Sienkiewicza) oraz postulowane przez niego projekty społeczne, np. nowoczesna filozofia zdezalienowanej pracy, idee swobodnej wytwórczości i syndykalizmu w nowym społeczeństwie itp. W wyraźny sposób wzbogacają one przyjętą tu tezę interpretacyjną i jej egzemplifikację.

Mój postkolonialny dyskurs na temat twórczości Brzozowskiego wchłania wiedzę o politycznej i kulturowej kolonizacji Polski przełomu XIX i XX wieku i chce uwzględniać $\mathrm{w}$ tym zakresie kolonialne struktury kultury i literatury polskiej tudzież reakcję na nie wybitnego krytyka. Kolonialny i postkolonialny aspekt utworów powieściowych i eseistycznych autora Płomieni prosi się o uwzględnienie $\mathrm{w}$ analizach jego twórczości chociażby $\mathrm{z}$ racji genezy i funkcji zawartych $\mathrm{w}$ niej treści datowanych w szczególnym momencie historycznym. Wtedy kontynuowana była i rozszerzana m.in. przez rewolucję 1905 roku walka o narodowe wyzwolenie i wywalczenie niepodległości było już blisko.

${ }^{6} \mathrm{~W}$ chwili oddania artykułu do druku nieznana mi była całość książki M. Wyki, Czytanie Brzozowskiego (Kraków 2012).

7 Por. G. Ch. Spivak, Strategie postkolonialne. Red. S. Harasym. Warszawa 2011. 


\section{II}

Teksty Brzozowskiego ujmowane w świetle teorii postkolonialnej oraz mojej propozycji rozszerzającej $\mathrm{w}$ tym aspekcie dotychczasowe ich interpretacje mogą okazać się ważkimi literackimi przykładami relacji kolonializmu z postkolonializmem, jeśli przyjąć metodologię Ani Loomby8. Zdaniem Brzozowskiego, polską powieść postpozytywistyczną (m.in. autorstwa Henryka Sienkiewicza i jego epigonów) w dużej mierze autoryzuje i legitymizuje sarmatyzm jako podłoże tożsamości kulturowej i narodowej. Brzozowski wykazuje, że w tych utworach - jakby to określiła Leela Gandhi - „styl i sposób narracji oraz treści fabuły okazują się nieodzowne dla konsolidacji władzy" świadomości kolonialnej vs. skolonizowanej9. Brzozowski we Wspótczesnej powieści polskiej, Wspótczesnej krytyce literackiej i Legendzie Młodej Polski - by ograniczyć się tylko do przykładu tych najbardziej znanych jego książek - zdaje się utrzymywać, iż świadomość kolonialna i ówczesna polska powieść "tak dalece wzajemnie siebie wzmacniały, że nie jest możliwe - jakby to ujął Edward Said - „by odczytywać jedno, w jakiejś mierze nie zajmując się drugim"10.

Aczkolwiek powieści Brzozowskiego nie są, rzecz biorąc genologicznie, powieściami historycznymi - związki kolonializmu i postkolonializmu z procesami historycznymi są szczególnie silne. To są typowe „powieści idei”, idei przezwyciężających ustroje i kultury kolonialne. Pisarstwo Brzozowskiego reprezentuje wręcz w modelowej postaci historyczną sytuację społeczną przejścia na ziemiach polskich od doby kolonialnej ku projektowi swobody po wyzwoleniu z politycznie kolonialnej oraz mentalnej zależności od krępującej społeczny rozwój tradycji. W tym sensie główni bohaterowie powieści Brzozowskiego wyzwalają się z romantycznego mitu Kresów, powieściopisarz za pomocą tych konstrukcji realizuje antymit kresowy ${ }^{11}$.

Brzozowski tworzył na krawędzi starej i nowej epoki, miał blisko przed sobą zarówno intelektualny jak i faktyczny wzlot w okres niepodległości. Swą twórczością stwarzał myślowy i praktyczny przeskok przez próg kolonialnej współczesności do stanu społeczeństwa postkolonialnego. Zobrazowaniu i zrozumieniu tej nowej sytuacji socjalnej poświęcona była twórczość Stanisława Brzozowskiego. Jego krytyka sarmatyzmu i polskiego romantyzmu jest szczególnym przykładem rodzimej refleksji o postkolonialnym charakterze, myśli, która „odkrywa kolonial-

\footnotetext{
8 A. Loomba, Kolonializm / poskolonializm. Przeł. N. Bloch. Poznań 2011.

${ }^{9}$ L. Gandhi, Teoria postkolonialna. Wprowadzenie krytyczne. Przeł. J. Serwański. Poznań 2008, s. 129.

${ }^{10}$ Ibidem.

${ }^{11}$ Por. B. Bakuła, Kolonialne i postkolonialne aspekty polskiego dyskursu kresoznawczego (zarys), „Teksty Drugie" 2006, nr 6; M. Dąbrowski, Kresy w perspektywie krytyki postkolonialnej, w: idem, Komparatystyka dyskursu / Dyskurs komparatystyki. Warszawa 2009.
} 
ne składniki własnej historii" - jak to określa Doris Bachmann-Medick ${ }^{12}$. Wypróbujmy ten pojęciowy arsenał w niekończącej, jak się zdaje, podróży „looking for Brzozowski".

Przeprowadzaną $\mathrm{w}$ pismach Brzozowskiego rewizję zarówno staroszlacheckiej, romantycznej, jak i młodopolskiej kultury warto obserwować, jako przezwyciężanie owych tradycji na, co najmniej, dwóch obszarach myśli. Po pierwsze, stanu historycznie określonego skolonizowania ojczyzny pisarza przez ówczesnych zaborców oraz, po drugie - oddziaływania postulowanego przezeń paradygmatu postkolonialnego. Nie bez podstaw można sądzić, iż owe kategorie stosowane przez teorię postkolonialnych studiów nad kulturą i literaturą narzucają się dzisiaj jako absolutnie nowe $\mathrm{w}$ dotychczasowym stanie badań nad twórczością Brzozowskiego $^{13}$. A zarazem jako całkowicie naturalne i adekwatne wobec tego pisarstwa $\mathrm{z}$ racji jego treści i ich funkcji w sytuacji cywilizacyjnego i politycznego przełomu w Polsce oraz w Europie Środkowej XIX i XX wieku w kontekście istnienia tzw. „białego kolonializmu”.

Dokonywaną przez Brzozowskiego krytyczną rewizję literackiej młodopolszczyzny można zasadnie interpretować jako śmiałą dekonstrukcję tej formacji kulturalnej. Autor Legendy Młodej Polski wystąpił z tą inicjatywą w stylu avant la lettre postmodernisty. Na młodopolską kulturę i literaturę spojrzał przez pryzmat jej cywilizacyjnego zapóźnienia, umysłowego zniewolenia i nolens volens skolonizowania. Bacznie obserwował i opisywał te stany świadomości podczas swego życia w kraju, jak i pobytu we Florencji, gdy konfrontował je zarówno z wówczas gwałtownie przyspieszającą po zjednoczeniu kraju cywilizacją włoską oraz z przewodnimi ideami współczesnej literatury Zachodu, zwłaszcza - angielskiej ${ }^{14}$.

Cała twórczość Brzozowskiego daje się interpretować jako wielki apel o modernizację stylu życia narodu niezbędną $\mathrm{w}$ perspektywie przyszłego odzyskania państwowości. Było to wezwanie sformułowane $\mathrm{w}$ okresie politycznego i cywilizacyjnego przełomu, gdy także „nie brakowało objawów dowodzących, że niewola stawała się przyzwyczajeniem"15. Nie były to bynajmniej problemy pozorne. W tej sytuacji pisma Brzozowskiego spełniały funkcje także pedagogiczne i były adresowane do społeczności „rozbrajanej bezpaństwowością kraju i spadkiem po szlacheckiej kulturze, obyczajowości i psychice, żyjącej w kulcie tej kulturowej tradycji [...] Polska odzwyczajona od państwowości [...] kiedy ją odzyska, będzie

12 D. Bachmann-Medick, Cultural turns. Nowe kierunki w naukach o kulturze. Przeł. K. Krzemieniowa. Warszawa 2012, s. 215; Por. E. Thompson, Sarmatyzm i postkolonializm. „Europa” 2006, nr 46.

${ }^{13}$ Taki walor posiadają studia Ewy Paczoskiej, m.in. Z perspektywy „obcego". Sttumienia kultury polskiej wedtug Stanisława Brzozowskiego, w: eadem, Prawdziwy koniec XIX wieku. Śladami nowoczesności. Warszawa 2010.

${ }^{14}$ W. Krajewska, Związki twórczości Stanistawa Brzozowskiego z literatura angielska, w: Wokót myśli..., op. cit.

15 T. Burek, Niewybaczalne sentymenty. Warszawa 2011, s. 20. 
musiała szukać wzoru, tradycji, przykładów"16. W Legendzie Młodej Polski autor pisał, że nic go bardziej nie razi i nie boli, jak niechęć, z jaką rodacy odbierają „dzieło zbiorowego życia innych narodów [...] nie umieją spojrzeć na [...] żywoty zwane Francją, Anglią, Włochami, Niemcami nowoczesnymi"17.

Bronisław Chlebowski tak zauważył i scharakteryzował ten okres pracy Brzozowskiego i formułowane przezeń przestrogi dla Polski przed postępującą kolonizacją kraju:

Współczesne odrodzenie Włoch, znajdujące swój wyraz w rozwinięciu energicznej, wszechstronnej działalności przemysłowej, społecznej, politycznej i umysłowej, wywierało silny wpływ [na Brzozowskiego - dop. K.K.], potęga i świetność kulturalna Anglii [...] pobudzały do szukania $\mathrm{w}$ organizacji duchowej wybitnych przodowników [...], wskazówek drogi, jaką kroczyć powinno społeczeństwo polskie dla wytworzenia i utrzymania swej kultury wśród zagrażających mu wchłonięciem organizmów państwowych i struktur kulturalnych Niemiec i Rosji18.

\section{III}

Krytyka młodopolskiego modernizmu przez Brzozowskiego, jej performatywny styl i stosowana argumentacja zachęca - jak się rzekło - do zaadaptowania $\mathrm{w}$ analizie jego pisarstwa narzędzi kulturowych studiów kolonialnych i postkolonialnych. Z punktu widzenia rekonstrukcji społecznych i krytycznoliterackich projektów autora Widm moich wspótczesnych można stwierdzić, iż krytyk podjął się zadania uwolnienia naszej kultury, skolonizowanej i zdominowanej przez anachroniczny model szlachecko-ziemiańskiej obyczajowości a następnie wykreowania, choćby tylko w zarysie, jej sytuacji i warunków postkolonialnych. Biorąc to pod uwagę, o powieściowych i krytycznoliterackich propozycjach Brzozowskiego można stwierdzić, iż są wskazaniem drogi swoistego postkolonialnego programu społecznego i kulturalnego. Autorowi Głosów wśród nocy chodziło przede wszystkim o otwarcie nowej przestrzeni refleksji humanistycznej, usytuowanej pomiędzy odrzucanym i skompromitowanym, bo skolonizowanym przez kompleksy złej tradycji wzorem kultury a otwartymi, postkolonialnymi możliwościami. Wielu interpretatorów twórczości Brzozowskiego, m.in. Tadeusz Sławek twierdzi, iż do dzisiaj zachowała aktualność dokonana przez pisarza krytyka prowincjonalności

\footnotetext{
${ }^{16}$ R. Zengel, Przed renesansem Brzozowskiego, w: idem, Mit przygody i inne szkice literackie. Wybór i wstęp T. Burek. Warszawa 1970, s. 103.

17 S. Brzozowski, Legenda Młodej Polski. Studia o strukturze duszy kulturalnej. Lwów 1910, s. 266-267.

${ }_{18}$ B. Chlebowski, Spuścizna Brzozowskiego, w: idem, Od Kochanowskiego do Brzozowskiego. Wybór i wstęp A. Biernacki. Warszawa-Kraków 1979, s. 532.
} 
ówczesnej polskiej kultury ${ }^{19}$ - dodajmy: tego widomego znaku jej kolonialnej sytuacji i statusu. Godzi się także w tym miejscu zauważyć, że Brzozowski dzięki swej twórczości został uznany w XX wieku za wybitnego dekonstruktora starych "przeterminowanych" wzorów kultury. Świadczy o tym, odnawiana przez całe ubiegłe stulecie, recepcja jego dzieła, przedłużona przez kolejną już jej eksplozję $\mathrm{w}$ rocznicowym 2011 roku.

Za Tadeuszem Sławkiem godzi się też powtórzyć, że:

Myśl Brzozowskiego jest [...] szczególnie wartościowa, gdyż odrzuca pielęgnowany przynajmniej od XVII wieku mit narodowego zamknięcia, który odegrał tak istotną rolę w kształtowaniu polskiej kultury [...] Polska zamykała się przeciwko reszcie Europy, popełniając tym samym podwójny i śmiertelnie niebezpieczny grzech zapomnienia o »Innym«, proponując bezkonfliktowe odczytanie kultury jako powtarzalnego cyklu rytuałów ${ }^{20}$.

W tym kontekście należy też osadzić najgłośniejszą polemikę Brzozowskiego, której znaczenie akcentowali zarówno komentatorzy współcześni, jak i późniejsi. Już wspomniany Bronisław Chlebowski pisał:

Namiętność, z jaką Brzozowski prowadził walkę przeciw potężnemu wpływowi Sienkiewicza [por. też w tym kontekście głośny esej Witolda Gombrowicza Sienkiewicz - dop. K.K.] staje się zrozumiałą i usprawiedliwioną, gdy weźmiemy pod uwagę przeciwstawność [...] ideową i społeczną Polski odbitej w [...] Trylogii i w Połanieckich z wizją Polski robotniczej [...] Legendy Młodej Polski ${ }^{21}$.

Warto zaznaczyć, iż rozpatrywanie przez obu pisarzy, Brzozowskiego i Gombrowicza, społecznego fenomenu pisarstwa Sienkiewicza jako sarmacko „kolonizującego" świadomość czytelników pozostaje w całkowitej zgodzie z teorią badań nad kolonializmem i postkolonializmem. Jak bowiem wskazują badacze tych zagadnień: „kolonializm nie jest wyłącznie rezultatem oddziaływania sił zewnętrznych na dany naród czy kraj [...] ale wyłania się także za sprawa czynników zewnętrznych, które przyczyniają się do jego powielania"22.

Wiele postaci $\mathrm{w}$ powieści Brzozowskiego, w tym przede wszystkim główni bohaterowie (Michał Kaniowski z Płomieni i Roman Ołuski z Sam wśród ludzi), to nosiciele, ale zarazem rewizjoniści tradycyjnych wad polskiej szlachty skolonizowanej przez zabory. Te wady to m.in. bezsiła, bezwola działania, zgoda na życiowe porażki, przybieranie męczeńskich póz. Pisarz „piętnuje zaściankowość, cia-

${ }^{19}$ T. Sławek, "Post-modernizm” a re-wizja wspótczesności. Kilka uwag o Stanistawa Brzozowskiego krytyce modernizmu, w: Postmodernizm w literaturze i kulturze krajów Europy Środkowo-Wschodniej. Red. H. Janaszek-Ivaničková, D. Fokkema. Katowice 1995, s. 38.

${ }^{20}$ Ibidem, s. 35.

${ }^{21}$ B. Chlebowski, op. cit., s. 533.

22 A. Loomba, op. cit., s. 27. 
snotę umysłową, brak wszelkiej pogłębionej refleksji nad życiem [...], żenującą naiwność recept egzystencjalnych"23. Charakter tych kulturowych stłumień i patologii dobrze jest widoczny w perspektywie teorii postkolonialnej. Czy dysponując takim bagażem świadomości można wydobyć się ze społecznego impasu i czy można skutecznie się zdekolonizować? - jakby pytał Brzozowski w swoich powieściach. Dlatego Ewa Paczoska przedstawia Brzozowskiego jako analityka stłumień kultury, widzianych w perspektywie wykluczającej się postkolonialnej nowoczesności. Prześledzenie dotychczasowego stanu badań nad twórczością pisarza i filozofa prowadzi do wniosku, iż jej kontekst postkolonialny pozostawał niezauważony aż do niedawnych publikacji Paczoskiej. Między innymi wypada powtórzyć za badaczką, że „w tym kontekście warto czytać Brzozowskiego, ponieważ mówi on o „złudnej wspólnocie” i niekiedy społecznej patologii polskiej familijności w sytuacji niewoli i bez kontaktu ze współczesnym światem ${ }^{24}$. Brzozowski swą twórczością powieściową i eseistyczną m.in. dokonywał wyrazistego zwrotu $\mathrm{w}$ tradycyjnym literackim obrazie rodziny, konfrontując stary i nowy model obyczajowości i patriotyzmu. $Z$ tego względu jego teksty swobodnie mieszczą się $\mathrm{w}$ ramach diagnozy "destrukcji rodzinnego ładu pod wpływem przemian zachodzących w społeczeństwie niewolnym i jednocześnie wkraczającym w nową epokę społecznej komunikacji"25. Epokę tę określają w Polsce i w Europie Środkowej m.in. zapoczątkowane procesy politycznej i kulturowej dekolonizacji i demokratyzacji przełomu XIX i XX wieku.

Brzozowski tak konstruuje biografie swoich problematycznych bohaterów „powieści idei”, iż okazuje się, że można przeciwstawić się kolonializmowi. Lokuje się w nowej społecznie sytuacji, dla mnie - postkolonialnej. Wydobywają się z politycznej i kulturowej izolacji, charakterystycznej zwłaszcza dla ziemiaństwa kresowego. Brzozowski poprzez kreacje bohaterów swoich powieści wyraża m.in. „pogardę dla romantyki, która wybrała drogę łatwej ewakuacji ze świata, można usłyszeć echo słynnego potępienia kultu eskapistycznego irracjonalizmu, jakiego w podobnym czasie dokonał Max Weber"26. To jeden z głównych, jak wiadomo, obok Stanisława Brzozowskiego, twórców dwudziestowiecznego odczarowania starego typu mentalności i wzorów kultury.

Przy lekturze powieści Brzozowskiego chciałbym zdecydowanie wykroczyć poza konwencje przypisującą te utwory li tylko do gatunku powieści historycznej o terrorystach z szeregów Narodowej Woli czy o „wysadzonej z siodła” szlachcie $\mathrm{w}$ okresie międzypowstaniowym (np. Antoni Sygietyński, Wysadzony z siodła,

\footnotetext{
${ }^{23}$ A. Bielik-Robson, Syndrom romantyczny. Stanistaw Brzozowski i rewizja romantyzmu, w: eadem, Romantyzm, niedokończony projekt. Eseje. Kraków 2008, s. 79.

${ }^{24}$ E. Paczoska, Prawdziwy koniec XIX wieku..., op. cit., s. 110.

25 Ibidem, s. 107.

${ }^{26}$ A. Bielik-Robson, op. cit., s. 84.
} 
1890). Zarówno wizja fabularna, jak i projekt społeczny przedstawiony w tych powieściach jest znacznie szerszy. Już w przeszłości przedstawiano prolegomena do zarysu „postkolonialnej” ich lektury (np. Michał Borowicz, Tomasz Burek). Tomasz Burek stwierdził m.in., że „potrzebna byłaby próba spojrzenia na powieści Brzozowskiego z perspektywy przyszłości: nie od strony tego, co było przed nimi, lecz od strony tego, co po nich dopiero miało w literaturze nastąpić" ${ }^{27}$. W zestawieniu z ówczesną powieścią polityczną Andrzeja Struga czy z nurtem psychologicznym, reprezentowanym m.in. przez Z. Nałkowską, M. Komornicką, S. Licińskiego, J. Korczaka, Brzozowski jako krytyk lansował nowoczesną powieść angielską, m.in. J. Conrada i W. M. Thackeraya. O ile wymienieni pisarze polscy akcentowali zjawiska czysto psychiczne, o tyle dla Brzozowskiego znamienny jest cel: przełamywanie świadomości ustroju i kultury kolonialnej.

Brzozowski w swoich pismach uwzględnia dwa wyróżniane rodzaje kolonizacji, również ten zewnętrzny. Ale niewątpliwie jego intelektualną specjalizacją a zarazem innowacją stał się ten wewnętrzny składnik mentalny, czynnik skolonizowania społecznej świadomości. Karol Irzykowski stwierdził, iż w wyniku rewolucji 1905 roku Młoda Polska, jako formacja artystyczna, „przez jedną noc posiwiała", momentalnie zdezaktualizowała się ${ }^{28}$. Powyższy bon mot Irzykowskiego w tym samym, jeśli jeszcze nie większym, stopniu odnieść można do siły oddziaływania najważniejszej książki Brzozowskiego, Legenda Młodej Polski. Według dość powszechnie przyjętej opinii Brzozowski tą książką zdekonstruował współczesną mu krajową formację kulturalną. W jaki sposób tego dokonał? Odpowiedzi na to pytanie były różne ${ }^{29}$. Ja dodaję taką, która jeszcze wyraźnie nie padła. Na twórczość Stanisława Brzozowskiego można i należy spojrzeć także w kategoriach zaproponowanych przez studia kolonialne, albowiem kulturowa i krytycznoliteracka kreacja tego pisarza ściśle koresponduje $\mathrm{z}$ dyskursem stosowanym $\mathrm{w}$ teorii postkolonialnej.

27 T. Burek, Arcydzieło niedokończone. „Twórczość” 1966, nr 6.

${ }^{28}$ K. Irzykowski, Dwie rewolucje, w: idem, Czyn i stowo. Kraków 1980, s. 216-217.

${ }^{29}$ Np. M. Wyka, O niektórych terminach krytycznych "Legendy Młodej Polski”, w: Prace ofiarowane Henrykowi Markiewiczowi. Red. T. Walas. Kraków 1984. 